\title{
Cross-sectional assessment of infants' exposure to toxic metals through breast milk in a prospective cohort study of mining communities in Ghana
}

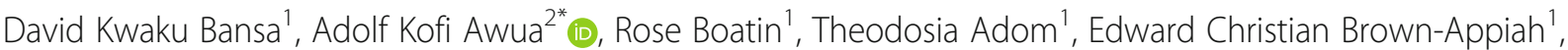 \\ Kennedy Kwame Amewosina', Akusika Diaba', Dominic Datoghe ${ }^{1}$ and Wilhelmina Okwabi ${ }^{3}$
}

\begin{abstract}
Background: Although breastfeeding of infants is recommended globally, the fact that maternal toxic metal stores are mobilised into breast milk implies infants, whose mothers live and work in mining communities, are at risk of multiple exposure to mining related toxic metals, such as Lead (Pb), Mercury ( $\mathrm{Hg})$, Cadmium (Cd) and Arsenic (As), through breast milk intake, in addition to in utero exposure.

Method: A total of 114 mother-baby pairs, recruited from two community hospitals servicing mining communities in two different regions in Ghana (57 each), were involved in this study. When the babies were 3 months old, the amount of breast milk intake, concentrations of selected toxic metals in the breast milk and therefore the amount of toxic metals exposure through breast milk were determined. The study also, determined the amount of these toxic metals in the hair and urine of each mother-baby pair at 3 months postpartum.

Results: Based on the amounts of milk intake and non-milk oral intakes (geometric mean of 0.701 (95\% CL 0.59-0. 81) $\mathrm{Kg} /$ day and median of $0.22 \mathrm{Kg} /$ day respectively), $90 \%$ of the babies were determined to have been exclusively breastfed. The amounts of most of the toxic metals in breast milk were higher than the WHO set limits and for 46. $4 \%, 33.3 \%$ and $4.4 \%$ of the babies, their intake of $\mathrm{As}, \mathrm{Hg}$ and $\mathrm{Pb}$ respectively were above the $\mathrm{WHO}$ provisional tolerable daily intake (PTDI) values.

Conclusion: An appreciable proportion of babies living within the communities served by the Mangoasi Community Hospital in the Obuasi Municipality of the Ashanti Region and the Dompime Health Centre in the Tarkwa Municipality of the Western Region were exposed to Hg, As and Pb through breast milk in excess of what they should and these may have health implication for the infants and therefore calls for interventions.
\end{abstract}

Keywords: Heavy metals, Mercury, Arsenic, Cadmium, Breast feeding, Breast milk, Deuterium Enrichment, Mining

\section{Background}

Breast milk is an incomparable food for infants, as such, it is globally recommended that infants be exclusively breast fed for the first six months of their lives and if possible breast fed until 2 years of age or older (WHO; infant and young child nutrition, 2012; WHO/UNICEF. Global Nutrition Targets, 2014). This recommendation was based

\footnotetext{
* Correspondence: a_awua@yahoo.com

${ }^{2}$ Cellular and Clinical Research Centre, Radiological and Medical Sciences Research Institute, Ghana Atomic Energy Commission, Accra, Ghana

Full list of author information is available at the end of the article
}

on the facts that breast milk contains all the micro- and macro- nutrients that an infant needs for healthy growth. Additionally, it contains protective proteins, including antibodies and enzymes, that help fight infections in infants [1]. As is known for most functional proteins found in the human body fluids, some of the proteins in human breast milk interact with metals ions such calcium, zinc, iron and toxic metals to form functional or dysfunctional metalloproteins $[2,3]$. Since maternal toxic metal stores, including those in blood, are mobilised into break milk during pregnancy and lactation [4], infants may be exposed to 
these toxic metals through breast feeding, particularly for infants whose mothers live and work in community with unregulated mining activities. The exposures to toxic metals have significant public health implication, even at small concentrations and acute exposures, these metals remain toxic to humans. For infants in particular, these exposures may have adverse effect on the developing central nervous system [5-8], leaving a life-long defect on their cognitive abilities.

In Ghana, women living in mining communities, including some who are pregnant, often depend on unregulated small scale mining activities for their livelihood. This is generally widespread in most mining communities. The activities of these small scale miners generally lead to the contamination of humans, animals and the environment with toxic elements from the inappropriate handling and disposal of the chemicals use and generate [9]. Globally, small scale mining activities have been identified as the largest contributor of mercury contamination by human activity [10]. For instance, in Ghana, via the processes of amalgamation, commonly called "galamsey", mercury and arsenic are introduced into the environment. This is because, the high concentrations of arsenic present in gold bearing ores in Ghana are not extracted and collected in the appropriate manner by these small scale miners [11]. Consequently, there are numerous reports of environmental contamination by mercury, arsenic and other such toxic metals along the Ghanaian gold belt [12, 13, 11, 14-16]. Therefore, pregnant and lactating mothers who continue to live and depend on the unregulated small scaled gold mines for their livelihood may represent a group of mothers with a potentially high maternal mobilization of arsenic, mercury and other toxic elements. Additionally, since low-level methyl-Hg exposure during infancy has been shown to result from trans-placental acquisition from the mother, breast feeding, or the consumption of fish as a complementary food [17], there is a high risk of infants exposure to toxic metals in mining communities in Ghana.

In spite of this risk, most of the studies that have reported levels of toxic metal in breast milk and other nonhuman milk infant feeds often do not report the amounts of these toxic metals the infants were likely to have been exposed through such feeds. This is because these studies did not determine the amount of breast milk the infants consumed per day. Therefore, using a deuterium dilution technique, that makes it possible to measure the amount of human milk intake by breastfeeding infants [18], we present the study design of a prospective cohort study and mostly, a cross-sectional analysis that provide a quantitative estimate of the amount of selected toxic metals that infant were likely to have been exposed to through breast milk and indications that their burden of such metal are mostly contributed to by in utero exposure. We consider research and monitoring of the extent of infant toxic metals exposure, a public health priority.

\section{Methods \\ Study design \\ Study location}

This was a cross-sectional assessment (at 3 month followup time) of a prospective cohort study of breast-feeding mothers-baby pairs living in Tarkwa and Obuasi, two major mining municipalities in Ghana. The two municipalities were purposively selected for this study on the bases of three facts. These were, the high occurrence of mostly unregulated artisanal/small scale mining, the frequent report of high levels of toxic metal pollution in their environment and most importantly, the high numbers of pregnant women and nursing mothers participating in small scale mining activities in these communities. For each municipality, a hospital was selected, these were, 1) the Dompime Health Centre, which served Dompime and three other surrounding gold mining communities in the Tarkwa Municipality of the Western Region and 2) the Mangoasi Community Hospital in the Obuasi Municipality of the Ashanti Region, which served Mangoasi and seven other surrounding gold mining communities.

\section{Study population and sampling procedure}

Mother-baby pairs were recruited from among the population of breast-feeding mothers whose babies were between 2 and 3 months old and were resident within the study communities. At each of the two health facilities, mothers attending the Maternal Health Care Clinics were identified using the Standard Case Record Forms by only Nurses working in the respective hospitals. It should be noted that the total number of Standard Case Record Forms reviewed and the total number of women invited to participate were not record. Among these, breast-feeding mothers-baby pairs, who had been attending anti-natal clinic at these selected hospitals and were going to attend post-natal clinics at the hospitals or could be reached by the research team within the study communities, who had intended to continue breastfeeding for 12 months and had intended to continue living in the communities for a year from the time of recruitment were included in the study. However, mothers of twins, mothers who had complications or needed further medical attention after delivery, babies who had medical issues post-partum, mothers and infants who were HIV positive and mothers who stopped breast feeding were excluded from the study. Specifically, 73 and 64 mothers at Dompime Health Centre and Mangoasi Community Hospital respectively were recruited (totally 137 mothers); however, for each of the selected hospitals, 57 mother-baby pairs were reached at 3 months follow-up time, making a total of 114 mother-baby pairs. 
In line with the principles of research ethics, the mothers-baby pair who met the inclusion criteria but were not affected by the exclusion criteria were provided with all the information they needed in order to take an informed decision on participating in the study. Those who were willing were enrolled in the study after providing informed and parental consent for themselves and their babies respectively. Privacy was ensured during the completion of the questionnaire and the confidentiality of the data collected was ensured by using codes to identify participants' completed questionnaires and specimen. A summary of the study design is provided as Fig. 1 and below is a detailed description.

\section{Data and specimen collection}

At enrolment, data on mother and infant demographic characteristics and locator information were collected with a structured questionnaire, by a one-on-one interviewbased questionnaire administration. However, information on the number live birth, and the current number of children, in addition to the new birth were not collected. Participating mother-baby pairs were subsequently followed-up when the babies attained the ages of 3, 6, 9 and 12 months for specimen collection. Subsequent determination of breast milk intake per day, mothers' and infants' body compositions were made. During each of these follow-up times, the pair were contacted on 7 non-continuous days as follows; the first day was referred to as day 0 and the four days thereafter as days 1, 2, 3, and 4, and also on the 13th and 14th days after the first day. Participants who did not show-up at the hospitals were followed up at home.

On the first day (day 0) of each of the follow-up visits at 3, 6, 9 and 12 months, health data (maternal health indicators, morbidity and mortality) were collected with a structured questionnaire, and anthropometric measurements (Length/height, weight and mid upper-arm circumference) were taken. Thereafter, saliva samples (referred to as pre-dose) were collected from both mother and baby of each pair, after which deuterium dose was administered to the mother only. On days 1, 2, 3, 4, 13 and 14, post-dose saliva samples were collected from both mother and baby of each pair. Subsequently, samples of the following biological specimen were collected, breast milk (on any day after day 2), hair (on day 14) and urine (day 14). Details of these are as follows.

\section{Anthropometric procedures}

Length of infants and height of mothers were measured (to the nearest $0.1 \mathrm{~cm}$ ) using an infantometer and Stadiometer respectively). The weight for mothers and infants (to the nearest $0.1 \mathrm{~kg}$ ) were measured using an adult SECA Electronic Scales and the mid upper-arm circumference (to the nearest $0.1 \mathrm{~cm}$ ) using SECA Centimeter Tape Measure, all by trained field assistants at each follow-up time. All measurements were taken on day 0 and in addition, the weight and length of the pair were measured again on days 14. Body mass index (BMI) of the mother was calculated with the anthropometric data collected and the WHO Zscores for infants were determined (data not shown).

\section{Dose to mother deuterium enrichment method (DEM)}

The dose to mother deuterium enrichment method (DEM) used for this study is described below. This method has been shown to be safe for both infants and adults [18], and used in a number of studies for determining breast milk intake, energy intake and related nutritional determinations [18-24]. Mothers were given sterile cotton wool ball to soak up saliva by moving it around in their mouth until sodden. A sterile $20 \mathrm{~mL}$ disposable syringe was used to extract the saliva from the cotton wool into a labelled $5 \mathrm{~mL}$ sterile polypropylene tube. The process was repeated (each time with a new cotton wool) until about $4 \mathrm{~mL}$ pre-dose saliva had been collected. Babies' saliva samples were collected by moving a sterile wooden-spatula cotton wool swab around a baby's mouth until the cotton wool was sodden. Following the same procedure as for the mother, about $2 \mathrm{~mL}$ saliva was collected into a labelled $5 \mathrm{~mL}$ sterile polypropylene tube.

After the collection of the pre-dose saliva samples, a wellmixed standardized dose of deuterium oxide $(30( \pm 0.01) \mathrm{g}$, $99.8 \%{ }^{2} \mathrm{H}$ ) was given to each mother to drink, using a straw in order to avoid any spillage. The dose bottle was then well rinsed with $50 \mathrm{~mL}$ of drinking water and given to the mother to drink again using the same straw; this was to ensure that almost all the $30.0 \mathrm{~g}$ of deuterium labelled water dose was completely consumed by the mother. At 12 month, dose to baby for assessment of body composition was performed; that is, a standardised dose of $5.0 \pm 0.01 \mathrm{~g}\left(99.8 \%{ }^{2} \mathrm{H}\right)$ was prepared and served to the babies in a similar manner as described for the mothers and post dose saliva were collected as similarly.

\section{Breast milk intake and body composition}

Deuterium enrichment in saliva samples was measured using IRPrestige-21 Fourier Transformed Spectrometry (FTIR) (Shimadzu, Tokyo) and the data generated were used to compute the body composition of mother and baby (data not shown), non-milk oral intake per day and breast milk intake pair day of each baby at each follow-up. Specifically, body composition of mothers were estimated for each of the follow-up time 3, 6 and 9 months post-partum (data not shown), while the babies' body composition was estimated only at 12 month of age using collected saliva samples (data not shown). 


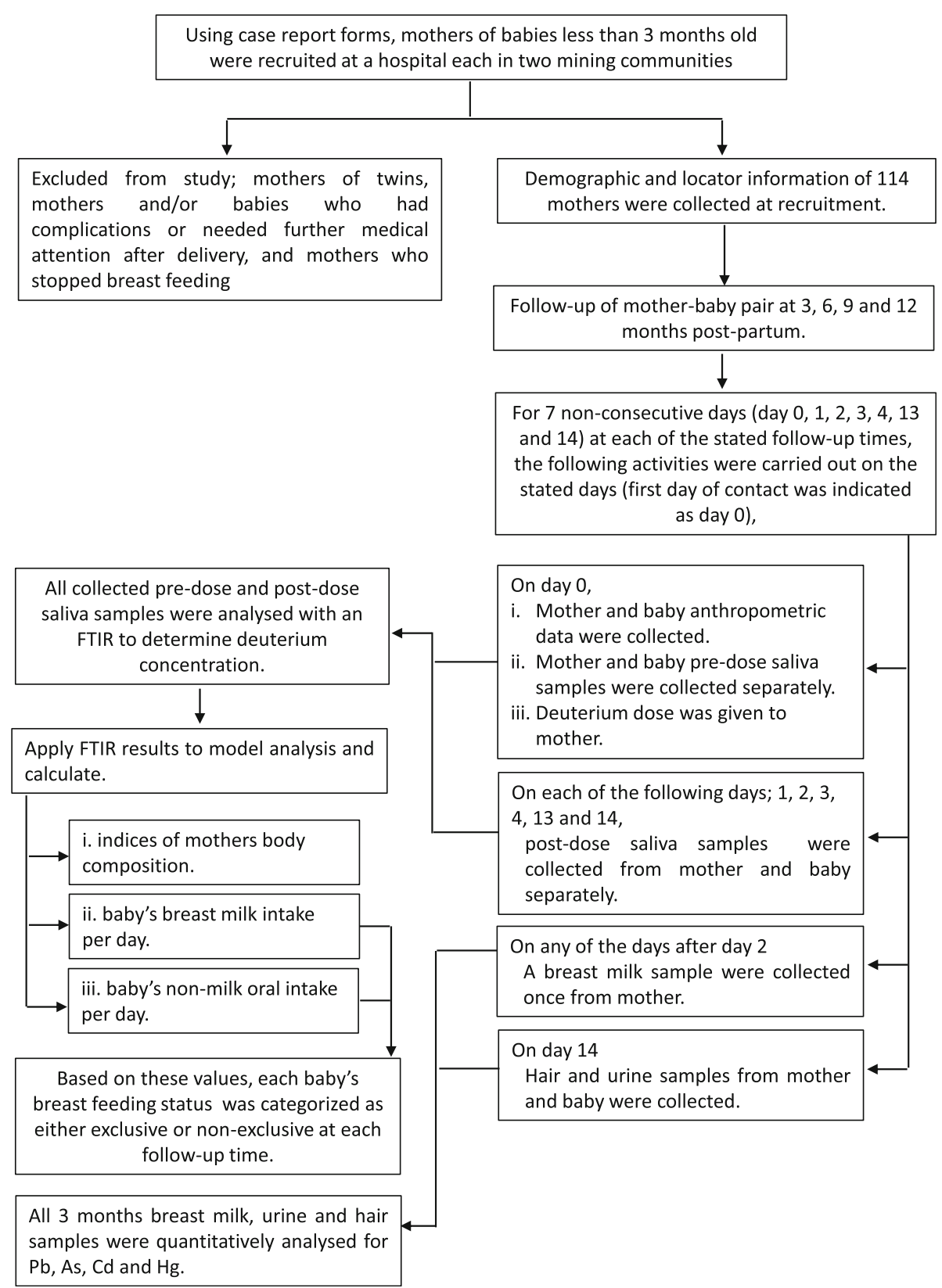

Fig. 1 An illustration of the study desgin of the prospective cohort study of breast-feeding mother-baby pairs in two mining coummunities in Ghana

\section{Determination of $\mathrm{Pb}, \mathrm{As}$ and $\mathrm{Cd}$ in breast milk and hair samples}

About $0.15 \mathrm{~g}$ of milk sample was weighed into quartz tubes. $1 \mathrm{~mL}$ of $65 \% \mathrm{HNO}_{3}$ (suprapur) and $1 \mathrm{~mL}$ of $30 \%$ $\mathrm{H}_{2} \mathrm{O}_{2}$ (suprapur) were added and the solution subjected to closed vessel microwave digestion at maximum power $(1500 \mathrm{~W})$ : ramp to $130{ }^{\circ} \mathrm{C}$ for $10 \mathrm{~min}$., ramp to $200{ }^{\circ} \mathrm{C}$ for $10 \mathrm{~min}$., hold for $20 \mathrm{~min}$. And then cooling for $20 \mathrm{~min}$. Thereafter, the solution was equilibrated to room temperature. The resulting solution was quantitatively transferred into polyethylene graduated tubes and made-up to $20 \mathrm{~mL}$ with Mili-Q water. The same procedure was applied to the blank (reagents and Mili-Q water in place of sample). Based on their appearance, digested solutions were diluted, if necessary, before measurements of concentrations of elements were taken with an Octapole Reaction System (ORS) Inductively Coupled Plasma Mass Spectrometer (7500ce. Agilent) equipped with an ASX-510 Auto-sampler (Cetac); two different modes of ORS (hydrogen and helium) were used. Quantification of all isotopes was performed using three central points of the spectral peaks. Instrumental 
conditions: nebulizer Micro Mist, spray chamber Scotttype, spray chamber temperature of $5{ }^{\circ} \mathrm{C}$, plasma gas flow rate of $15 \mathrm{~L} / \mathrm{min}$, carrier gas flow rate of $0.8 \mathrm{~L} / \mathrm{min}$, makeup gas flow rate of $0.1 \mathrm{~L} / \mathrm{min}$, nebulizer pump at $0.1 \mathrm{rps}$. RF power of $1500 \mathrm{~W}$, reaction cell gases: $\mathrm{H}_{2} 4 \mathrm{~mL} / \mathrm{min}$ and $\mathrm{He} 4 \mathrm{~mL} / \mathrm{min}$, isotopes monitored ${ }^{75} \mathrm{As},{ }^{111} \mathrm{Cd},{ }^{206} \mathrm{~Pb}$, ${ }^{207} \mathrm{~Pb}$, and ${ }^{208} \mathrm{~Pb}$. Tuning of the instrument was made daily using a solution containing Li. Mg. Y. Ca. Tl and Co. External calibration was used for quantification.

\section{Determination of $\mathrm{Hg}$ in breast milk and hair samples}

Concentration of total mercury in hair and milk samples was determined by the Direct Mercury Analyser DMA-80 (Milestone). The system integrates thermal decomposition sample preparation, amalgamation and atomic absorption detection. Specifically, between $20 \mathrm{mg}$ and $50 \mathrm{mg}$ of sample was weighed in a quartz boat and placed in an auto-sampler. The sample was thermally and chemically decomposed within the decomposition furnace at $650{ }^{\circ} \mathrm{C}$. An oxygen stream passing through the tube carried the remaining decomposition products through amalgamator that selectively trapped mercury vapour, which was subsequently desorbed for quantisation. Flowing oxygen carried the mercury vapour through absorbance cells positioned in the light path of a single wavelength atomic absorption spectrophotometer. Absorbance was measured at $254 \mathrm{~nm}$ as a function of mercury concentration.

The detection limits were; $\mathrm{Pb} 5 \mathrm{ng} / \mathrm{g}(0.00499 \mathrm{mg} / \mathrm{L})$, Cd 0.5 ng/g (0.000.499 mg/L), As 2 ng/g $(0.00199 \mathrm{mg} / \mathrm{L})$ and $\mathrm{Hg} 0.2 \mathrm{ng} / \mathrm{g}(0.000199 \mathrm{mg} / \mathrm{L})$. Quality control was performed by the use of the following reference materials: NIST 8435 Whole milk powder, BCR 150 Trace elements in a spiked skim milk powder, FAPAS 70172 milk powder inter-comparison material, and IAEA 086 Methyl mercury, total mercury and other trace elements in human hair.

\section{Determination of $P b, A s$, and $C d$ in urine}

Five millilitres of urine sample were measured into a previously acid washed labelled $100 \mathrm{ml}$ polytetraflouroethylene (PTFE) Teflon bombs. To each of the samples, $6 \mathrm{~mL}$ of concentrated nitric acid $\left(\mathrm{HNO}_{3}, 65 \%\right), 3 \mathrm{~mL}$ of concentrated hydrochloric acid (HCL,35\%) and $0.25 \mathrm{~mL}$ of hydrogen peroxide $\left(\mathrm{H}_{2} \mathrm{O}_{2}, 30 \%\right)$ were added in a fume chamber. The samples were loaded on the microwave carousel and the vessel caps were secured tightly using a wrench. The complete assembly was microwave irradiated for 26 min using milestone microwave labstation ETHOS 900, INSTR: MLS-1200 MEGA.

After digestion, the Teflon bombs mounted on the microwave carousel were cooled in a water bath to reduce internal pressure and allow volatilized material to restabilize. The digest was made-up to $20 \mathrm{~mL}$ with double distilled water and assayed for the presence of the metals using VARIAN AA 240FS-Atomic Absorption Spectrometer in an acetylene-air flame. Reference standards used for the elements of interest, blanks and duplicates of samples were digested in the same manner as the samples. These served as internal positive controls. Reference standards used were from Fluka Analytical, Sigma-Aldrich Chemie GmbH, and product of Switzerland.

\section{Data management and analysis}

Primary outcomes of the prospective cohort study were, 1) an estimate of the toxic metal intake through breast milk, 2) an estimate of micronutrient intake through breast milk, 3) determined breast feeding status based on the saliva sample analysis and how it correlates with self-reported breast feeding status, 4) body composition of the mothers at baseline and that of babies at end-line and 5) Nutritional status of mothers (MBI) and babies (WHO Z-score). However, this paper focuses on the first outcome, which is the estimation of toxic metals exposure through breast milk.

Deuterium enrichment data were entered into a premade Microsoft Excel data sheet and deuterium excretion curve was plotted for mother and baby according to the model provided by the Nutritional and Health-Related Environmental Studies Section of the International Atomic Energy Agency (IAEA). Curves fitting and calculation of endpoints (human milk intake, the baby intake of fluids other than human milk intake and mother and baby's body composition) was performed using pre-made Microsoft Excel data sheet (Human milk intake template FTIR calcs.xls). These calculated endpoints and other collected data (demographic, anthropometric, dietary intake) were transferred to a SPSS 20.0 database and analysed. The data for the 3 months follow-up are presented in the paper.

The amounts of human milk intake, and non-milk oral intakes were reported as means and 95\% CI and depicted as either line graphs with error bars or bar graphs. Differences in these amounts at different follow-up times were determined by either a student t-test or ANOVA at $95 \%$ CL. Geometric mean of the toxic metals (in breast milk, urine and hair) were compared. Categorical data were described as distributions of subgroups represented as percentages of total number of participants at each follow-up time.

\section{Results}

\section{Demographic information}

The mothers who participated in this study were young, with a mean age of 27.5 (95\% CI of 26.4-28.6) years and $83.5 \%$ were married. Furthermore, $79.8 \%$ had only secondary education while $59.5 \%$ were self-employed and $12.3 \%$ wage-employed, at the time of this study (Table 1). Interestingly, $41.1 \%$ of them own the house they lived in. 
Table 1 Distribution of the socio-demographic characteristics of the mothers

\begin{tabular}{lll}
\hline $\begin{array}{l}\text { Demographic } \\
\text { information }\end{array}$ & Categories & $\begin{array}{l}\text { Number, } n(\%) \\
(N=114)\end{array}$ \\
\hline Marital status & Married & $95(83.5)$ \\
& Living without a partner & $19(16.5)$ \\
Educational Status $^{*}$ & No formal education & $9(7.5)$ \\
& Alternative education & $4(3.9)$ \\
& Secondary & $91(79.8)$ \\
& Post-secondary & $10(8.8)$ \\
Employment status & Unemployed & $32(28.2)$ \\
& Wage employed & $14(12.3)$ \\
& Self employed & $68(59.5)$ \\
Home ownership & Rented & $67(58.9)$ \\
& Own property & $47(41.1)$ \\
\hline
\end{tabular}

*None of the women had stopped school at the Primary level nor were formally employed

\section{Breast milk and non-milk intake by infants at 3 months post-partum}

The amounts of breast milk consumed by the babies at the age of 3 months ranged between $0.33 \mathrm{Kg} /$ day and 2.16 $\mathrm{Kg} /$ day with a median of $0.7 \mathrm{Kg} /$ day and a geometric mean of 0.701 (95\% CL $0.59-0.81) \mathrm{Kg} /$ day. Within this wide range, a small proportion (10.0\%) of the babies recorded an intake of less than $0.500 \mathrm{Kg} /$ day, while $80.0 \%$ recorded intakes between $0.500 \mathrm{Kg} /$ day and $0.999 \mathrm{Kg} /$ day and another $10.0 \%$ recorded intakes higher than $1.000 \mathrm{Kg} /$ day. The box plot of the distribution of these intakes indicate that there were a few extremely high intakes of breast milk (Fig. 2). This figure also shows the distribution of the non-milk oral intake of the babies, showing a median of $0.22 \mathrm{Kg} /$ day and two extreme intakes.

\section{Toxic metals in mothers' breast milk at 3 months post- partum}

Results of the quality control materials for the toxic metals determination are shown in Table 2 below. These were within expected values and the standard deviation were minimal. As depicted in Table 3, the amount of arsenic (As) in breast milk ranged from $7 \mathrm{ng} / \mathrm{g}$ to $120.4 \mathrm{ng} / \mathrm{g}$ of milk with a median of $27.8 \mathrm{ng} / \mathrm{g}$ of milk and a geometric mean of 26.7 (95\% CI of 20.3-22.0) ng/g of milk. The toxic metal with the next highest geometric mean was lead $(\mathrm{Pb})$, this was 13.8 (95\% CI of $8.4-19.3) \mathrm{ng} / \mathrm{g}$ of milk within a range of 5.3 to $117.2 \mathrm{ng} / \mathrm{g}$ of milk and a median of $11.0 \mathrm{ng} / \mathrm{g}$ of milk. Mercury was detected within the concentration range of 1.36 and $63.5 \mathrm{ng} / \mathrm{g}$ of milk with a median of $8.4 \mathrm{ng} / \mathrm{g}$ of milk and a geometric mean of 7.6 (95\% CI of 5.1-10.1) ng/g of milk. Cadmium was the toxic metal with the lowest geometric mean, 1.23 (95\% CI of $0.96-1.50) \mathrm{ng} / \mathrm{g}$ of milk, which was within a

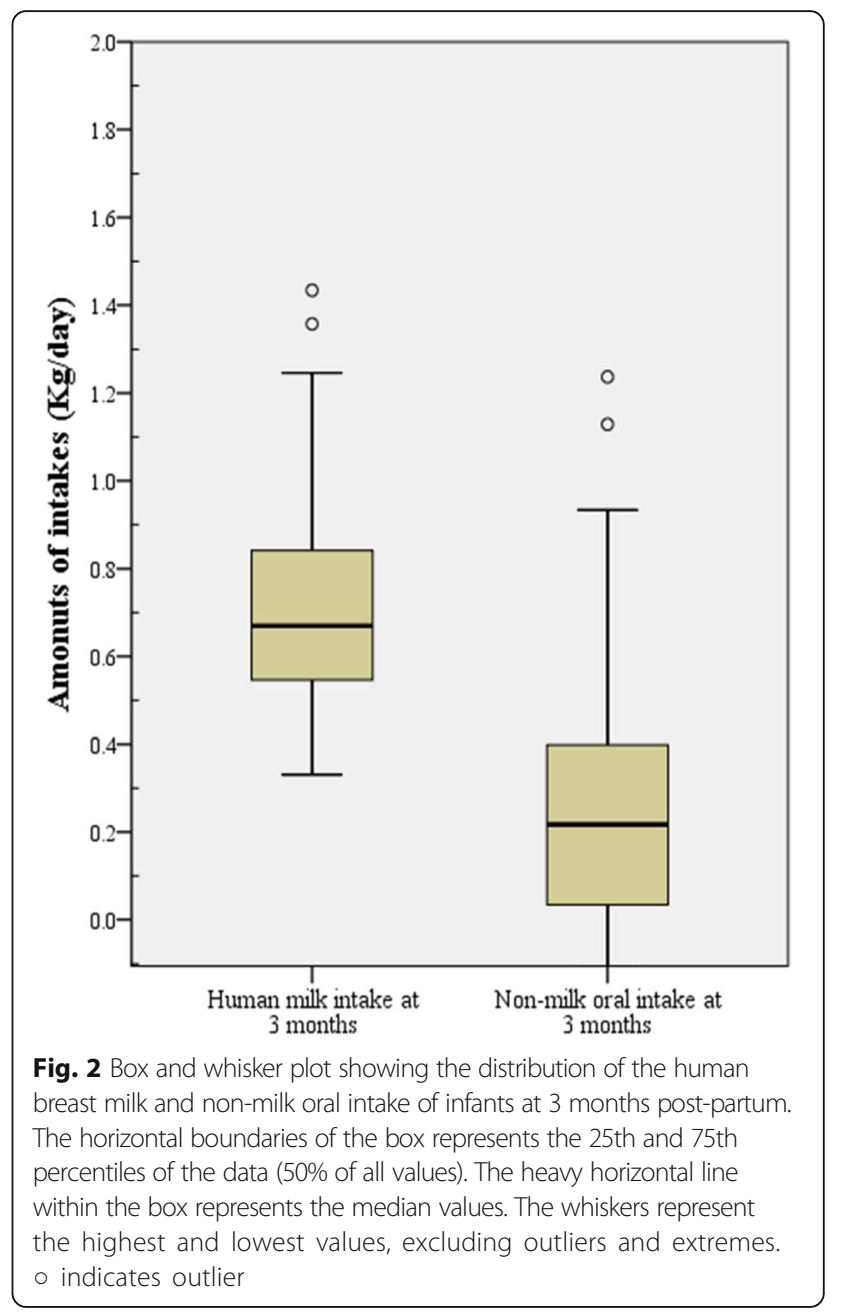

range of 0.60 to $6.3 \mathrm{ng} / \mathrm{g}$ of milk and recorded a median of $1.20 \mathrm{ng} / \mathrm{g}$ of milk.

Using the individual amounts of human breast milk intake of each infant and the amount of toxic metals detected in the respective mother's breast milk, an estimate of the amount of each toxic metal the infant was expected to be exposed to through breast milk was determined and the descriptive statistics of that data was presented as Table 4.

\section{Toxic metals excreted through urine}

The determination of the amounts of these toxic metal excreted by the babies through urine showed that lead was the most excreted, at a geometric mean concentration of 0.13 (95\% CI of $0.076-0.184) \mathrm{mg} / \mathrm{L}$ of urine (Table 5). The amounts of cadmium (Cd) excreted through the urine of the babies was 0.026 (95\% CI of 0.015-0.037) $\mathrm{mg} / \mathrm{L}$. The amounts of arsenic, and mercury excreted were low and close in value to the detection limits of the instrument used; specifically these 
Table 2 Amounts of toxic metal obtained for reference materials used for quality control

\begin{tabular}{|c|c|c|c|c|c|}
\hline \multirow[t]{2}{*}{ Quality Control Material } & \multirow[t]{2}{*}{ Descriptions } & \multicolumn{4}{|c|}{ Amounts of toxic metals (ng/g) } \\
\hline & & $\mathrm{Pb}$ & $\mathrm{Cd}$ & As & $\mathrm{Hg}$ \\
\hline \multirow{2}{*}{$\begin{array}{l}\text { IAEA } 086 \\
\text { Methyl mercury, total } \\
\text { mercury in human hair }\end{array}$} & analytical value \pm uncertainty & nd & nd & nd & $573 \pm 39$ \\
\hline & obtained result average \pm SD & nd & nd & nd & $530 \pm 24(n=32)$ \\
\hline \multirow{2}{*}{$\begin{array}{l}\text { NIST } 8435 \\
\text { Whole milk powder }\end{array}$} & reference value \pm uncertainty & $110 \pm 50$ & nd & nd & nd \\
\hline & obtained result average \pm SD & $90 \pm 5(n=8)$ & nd & nd & nd \\
\hline \multirow{2}{*}{$\begin{array}{l}\text { BCR } 150 \\
\text { Trace elements in a spiked } \\
\text { skim milk powder }\end{array}$} & reference value \pm uncertainty & $1000 \pm 40$ & $21.8 \pm 1.4$ & nd & $9.4 \pm 1.7$ \\
\hline & obtained result average $\pm S D$ & $1016 \pm 40(n=8)$ & $19.7 \pm 0.4(n=8)$ & nd & $8.3 \pm 0.7(n=34)$ \\
\hline \multirow{2}{*}{$\begin{array}{l}\text { FAPAS } \\
70,172 \text { milk powder } \\
\text { inter-comparison material }\end{array}$} & assigned value \pm uncertainty & $66.2 \pm 14.6$ & $18.6 \pm 4.1$ & $56.4 \pm 12.4$ & nd \\
\hline & obtained result average \pm SD & $48.9 \pm 3.5(n=8)$ & $17.0 \pm 1.1(n=8)$ & $46.9 \pm 3.0(n=5)$ & nd \\
\hline
\end{tabular}

nd not determined

were, $0.006(95 \% \mathrm{CI}$ of $0.003-0.007) \mathrm{mg} / \mathrm{L}$ and 0.004 (95\% CI of $0.003-0.005) \mathrm{mg} / \mathrm{L}$ respectively.

A similar pattern of excretion was observed with the mothers' urine (Table 5). Lead was the most excreted toxic metal, at a geometric mean of 0.331 (95\% CI of $0.267-0.395) \mathrm{mg} / \mathrm{L}$ of urine. The geometric mean amounts of cadmium was 0.022 (95\% CI of $0.011-0.034$ ) $\mathrm{mg} / \mathrm{L}$ and that of arsenic was 0.018 (95\% CI of 0.013$0.022) \mathrm{mg} / \mathrm{L}$. These were not significantly different from the amount of these toxic metal excreted by the infants. Similarly, the excreted amounts of arsenic, and mercury were low and close in value to the detection limits of the instrument used (Table 5).

Toxic metal eliminated through human hair

The amount of mercury ( $\mathrm{Hg})$ in the hair of mothers determined at 3 months post-partum varied within a wide range, from 0.11 to $6.99 \mu \mathrm{g} / \mathrm{g}$ of hair with a standard

Table 3 Amounts of toxic metals detected in mothers' breast milk

\begin{tabular}{lllll}
\hline Descriptive parameters & \multicolumn{4}{l}{$\begin{array}{l}\text { Amount of toxic metals, } \\
\text { (ng/g of milk }\end{array}$} \\
\cline { 2 - 5 } & As & $\mathrm{Pb}$ & $\mathrm{Hg}$ & $\mathrm{Cd}$ \\
\hline Geometric mean & 26.70 & 13.828 & 7.61 & 1.23 \\
SD & 20.30 & 23.692 & 10.72 & 1.17 \\
95\% CL (low) & 22.01 & 8.356 & 5.14 & 0.96 \\
95\% CL (high) & 31.39 & 19.301 & 10.09 & 1.50 \\
Median & 27.75 & 11.00 & 8.37 & 1.20 \\
Minimum & 7.00 & 5.30 & 1.36 & 0.60 \\
Maximum & 120.4 & 117.2 & 63.52 & 6.30 \\
WHO "normal condition levels" & - & $2.0-5.0$ & $1.4-1.7$ & 1.0 \\
in human breast milk (ng/mL) & & & & \\
WHO limits in drinking water & $10^{\mathrm{a}}$ & $10^{\mathrm{a}}$ & 0.500 & 1.0 \\
(ng/mL) $^{\mathrm{a}}$ & & & &
\end{tabular}

${ }^{a}$ Guideline with health implication; ${ }^{\mathrm{b}} 1 \mathrm{~g}$ of human breast milk is equivalent to $0.970 \mathrm{~mL} ;{ }^{\mathrm{cd}}[25]$ deviation of \pm 1.23 , a median of $1.03 \mu \mathrm{g} / \mathrm{g}$ and an interquartile range of $1.481 \mu \mathrm{g} / \mathrm{g}$ of hair (Fig. 3). On the other hand, the amount of $\mathrm{Hg}$ in the hairs of the 3 months old infants recorded an even wider range, from 0.300 to $19.00 \mu \mathrm{g} / \mathrm{g}$ of hair with a standard deviation of \pm 2.95 . The median for this data was $1.7665 \mu \mathrm{g} / \mathrm{g}$ of hair and the interquartile range was $3.12 \mu \mathrm{g} / \mathrm{g}$ of hair.

\section{Discussion}

In this prospective study of mother-baby pairs in two gold mining towns in Ghana, the deuterium dilution technique was successfully used to directly determine the amounts of breast milk intake of babies. As indicated in Fig. 2, the high median amount of breast milk intake and the low non-milk oral intake at 3 months after birth and the fact that a high proportion of babies $(90.0 \%)$ consumed between 0.500 and over $2.00 \mathrm{Kg} /$ day of milk were indicative

Table 4 Amounts of toxic metals intake by infants through human breast milk

\begin{tabular}{lllll}
\hline \multirow{2}{*}{$\begin{array}{l}\text { Descriptive } \\
\text { parameters }\end{array}$} & \multicolumn{4}{l}{ Heavy metals intake by infants, $(\mu \mathrm{g} / \mathrm{Kg}$ bw/day) } \\
\cline { 2 - 5 } & $\mathrm{As}$ & $\mathrm{Pb}$ & $\mathrm{Hg}$ & $\mathrm{Cd}$ \\
\hline Geometric mean & 2.901 & 1.363 & 0.940 & 0.129 \\
$\mathrm{SD}$ & 2.223 & 1.960 & 1.116 & 0.117 \\
95\% CL (low) & 2.388 & 0.910 & 0.682 & 0.102 \\
95\% CL (high) & 3.415 & 1.816 & 1.197 & 0.156 \\
Median & 3.19 & 1.17 & 0.94 & 0.13 \\
Minimum & 1.05 & 0.42 & 0.22 & 0.06 \\
Maximum & 7.05 & 10.56 & 5.23 & 0.42 \\
WHO PTDI & $2.1^{\mathrm{a}}$ & $3.57-5.0^{\mathrm{a}}$ & $0.57-0.8$ & $0.8-1.0$ \\
\% above WHO DPI & 46.36 & 4.35 & 33.33 & 0.00 \\
\hline
\end{tabular}

${ }^{a}$ withdrawn PTWI at the 2011 JECFA. Average weight of the 3 months old infants who participated in this study was $6.37(95 \% \mathrm{Cl}$ of $6.17-6.57) \mathrm{Kg}$. Evaluations of the Joint FAO/WHO Expert Committee on Food Additives (JECFA) 2011. http://apps.who.int/food-additives-contaminants-jecfa-database/chemical. aspx?chemID $=4197$ 
Table 5 Amounts of toxic metals excreted through mother and infant urine

\begin{tabular}{|c|c|c|c|c|c|c|c|c|}
\hline \multirow{3}{*}{$\begin{array}{l}\text { Descriptive } \\
\text { parameters }\end{array}$} & \multicolumn{8}{|c|}{ Heavy metals in urine, (mg/L) } \\
\hline & \multicolumn{2}{|l|}{$\mathrm{Pb}$} & \multicolumn{2}{|l|}{$\mathrm{Cd}$} & \multicolumn{2}{|l|}{ As } & \multicolumn{2}{|l|}{$\mathrm{Hg}$} \\
\hline & Infant & Mother & Infant & Mother & Infant & Mother & Infant & Mother \\
\hline Geometric mean & 0.13 & 0.331 & 0.026 & 0.022 & 0.006 & 0.018 & 0.004 & 0.004 \\
\hline SD & 0.234 & 0.277 & 0.048 & 0.049 & 0.005 & 0.02 & 0.003 & 0.004 \\
\hline 95\% CL (low) & 0.076 & 0.267 & 0.015 & 0.011 & 0.005 & 0.013 & 0.003 & 0.004 \\
\hline 95\% CL (high) & 0.184 & 0.395 & 0.037 & 0.034 & 0.007 & 0.022 & 0.005 & 0.005 \\
\hline Median & 0.250 & 0.39 & 0.01 & 0.01 & 0.0019 & 0.02 & 0.00 & 0.00 \\
\hline Minimum & 0.0049 & 0.01 & 0.01 & 0.01 & 0.0019 & 0.0019 & 0.00019 & 0.00019 \\
\hline Maximum & 0.74 & 0.90 & 0.15 & 0.15 & 0.02 & 0.08 & 0.007 & 0.01 \\
\hline
\end{tabular}

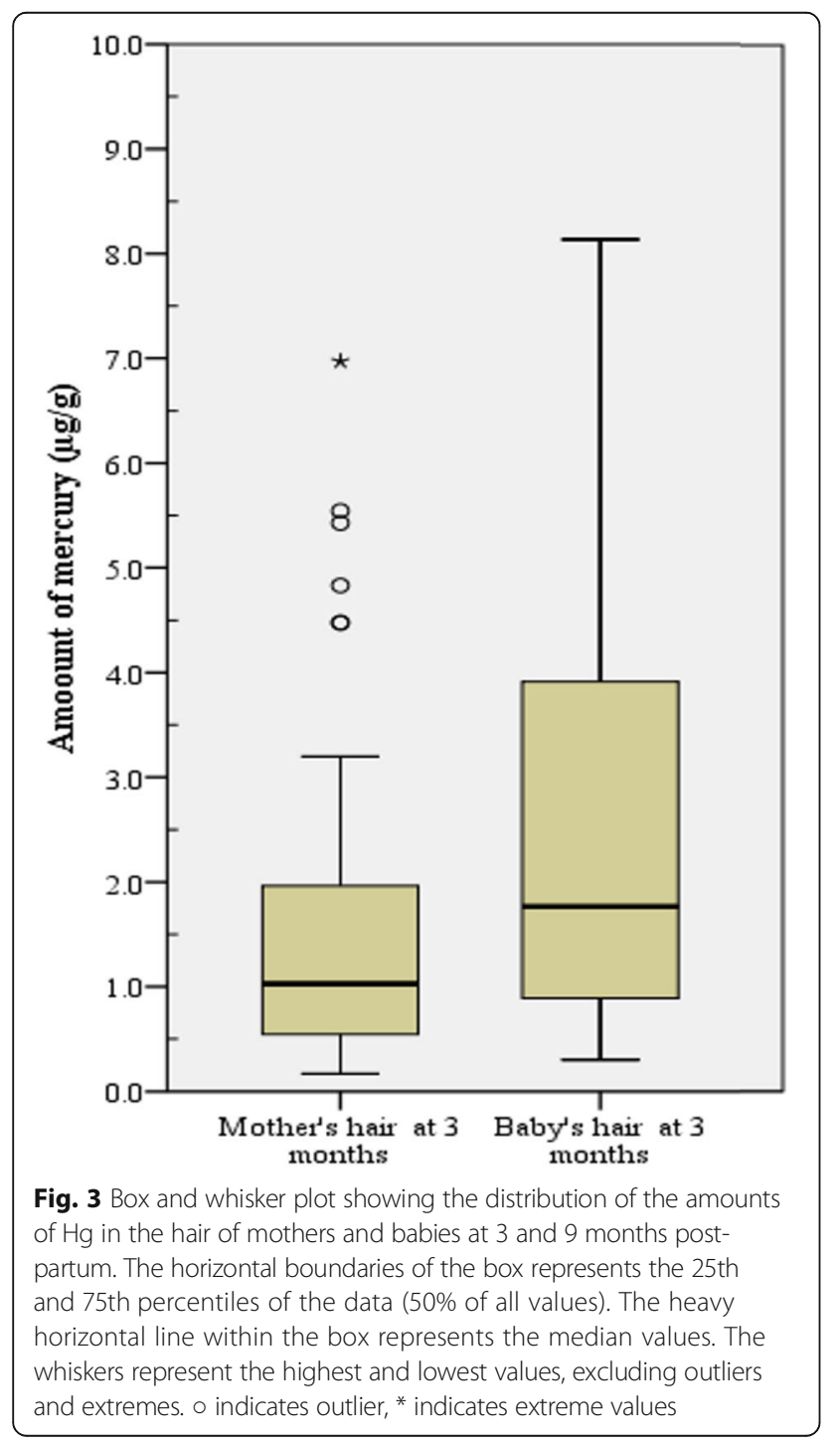

of the fact that the babies were well fed on breast milk. These high intakes of breast milk, although beneficial, necessitated the determination of the potential risks of consumption of mining related toxic metals through breast milk in mining communities. Specifically, an estimation of the intake of $\mathrm{Pb}, \mathrm{Hg}$, As and $\mathrm{Cd}$ through breast milk is of paramount importance. To the best of our knowledge, this is the first report of a direct estimation of the amounts of toxic metal intake by babies in Ghana and the sub-Saharan Africa region.

The observed variations in the geometric mean concentrations of these metals (Table 3) were to be expected, since the extent to which these metals are released into human breast milk naturally varies. For instance, the concentration of $\mathrm{Pb}$ has been shown to almost always be higher than the concentration of $\mathrm{Hg}$ and $\mathrm{Cd}$ in the same cohort of breast milk [8]. The first of the reasons for this, is that unlike $\mathrm{Hg}$ and $\mathrm{Cd}, \mathrm{Pb}$ accumulates in the bones of mothers over a long period of time and then during pregnancy, it is released into the blood and breast milk along with calcium. Secondly, only a very small proportion of maternal $\mathrm{Cd}$ is released into human breast milk because the proteins that bind $\mathrm{Cd}$ in breast milk, often bind more to calcium due to the high amount of calcium released into human breast milk, that is, there is competitive inhibition of the binding proteins of $\mathrm{Cd}$ [26]. Therefore the amount of $\mathrm{Cd}$ in breast milk is influenced by a mother's Ca levels. Finally, the biochemistry of the interactions of these metals and proteins in human breast milk are reasonably expected to vary and therefore will contribute to the inherent variation of these toxic metals in breast milk [27].

However varying these concentrations may be, the geometric mean [13.8 (95\% CI 8.356-19.301) ng/g of milk] (density of human milk is $1.030 \mathrm{~g} / \mathrm{mL}$ ) and maximum (117.2 ng/g of milk) amounts of lead $(\mathrm{Pb})$ reported for this study (Table 3 ) were both higher than the reported global mean and maximum amounts of lead concentration in breast milk, which are $5.0 \mathrm{ppb}$ (ng/g of milk) and $41.1 \mathrm{ppb}$ (ng/g of milk) respectively as indicated by the WHO, 
(1993). Additionally, the geometric mean amount of lead was higher than the WHO set "normal condition levels" for human breast milk, which indicates that breast milk may contain no more than $2-5 \mathrm{ng} / \mathrm{mL}(2.08-5.19 \mathrm{ng} / \mathrm{g}$ of milk) of lead [25]. These observed differences indicate that on the average, breast milk form the mothers in these mining areas of Ghana had about three times more $\mathrm{Pb}$ than it should. Additionally, these amounts (geometric mean and the maximum amount) of $\mathrm{Pb}$ were about three to four times higher than those $(4.83 \mu \mathrm{g} / \mathrm{L}$ and $32.0 \mathrm{ng} /$ $\mathrm{mL}$ respectively) reported by another study in a nonmining community in southern Ghana [28]. Compared to the mean amount of $\mathrm{Pb}$ in the breast milk of nomadic Fulani women in Nigeria, $102.0 \mu \mathrm{g} / \mathrm{L}$ (range 45.0 to $1300 \mu \mathrm{g} / \mathrm{L}$ ), the geometric mean of $\mathrm{Pb}$ in this study was far less. Furthermore, the amount of $\mathrm{Pb}$ intake in this study $(1.363 \mu \mathrm{g} / \mathrm{Kg} /$ day $)$ was about seven times less than that reported for the infants of the Fulani women in Nigeria $(9.9 \mu \mathrm{g} / \mathrm{Kg} /$ day). However, the study in Nigeria did not indicate specifically the reasons for this extremely high $\mathrm{Pb}$ in breast milk but only indicated that the diet of the Fulani community was heavily influenced by cattle, use of water mainly form wells and that there was a general reduced level of calcium [29]. On the other hand, the geometric mean of lead for this study was very similar to those reported by studies of breast milk obtained from women living in industrialised cities of Spain (15.56 (95\% CI 12.92-18.72) $\mu \mathrm{g} / \mathrm{L}]$ ) [8] and Iran $(7.11 \mu \mathrm{g} / \mathrm{L}$ (range 3.06-19.4 $\mu \mathrm{g} / \mathrm{L})$ ) [30]. The geometric mean amount of $\mathrm{Pb}$ in breast milk collected in this study was much more than that reported for mothers in a coastal community in Taiwan of $2.93 \mu \mathrm{g} / \mathrm{L}$ (range of $0.45-7.80 \mu \mathrm{g} / \mathrm{L}$ ) [31] and also that reported for a city in Poland, which reported $6.33 \mu \mathrm{g} / \mathrm{L}$ (range $0.486-12.01 \mu \mathrm{g} / \mathrm{L}$ ) and a median was $1.951 \mu \mathrm{g} / \mathrm{L}$ [32]. Together, these provide evidence to support the fact that high $\mathrm{Pb}$ concentrations may be from the environment or the industrialised activities within a community. Despite this high amount of lead in the breast milk, the estimated geometric mean of $\mathrm{Pb}$ intake per body weight, per day of 1.363 ; (95\% CI $0.910-1.816) \mu \mathrm{g} / \mathrm{Kg} /$ day (Table 4) was less than the WHO provisional tolerable daily intake (PTDI) of lead, which is set between 3.57 and $5 \mu \mathrm{g} / \mathrm{Kg} /$ day. Although the mean amount was lower than the WHO PTDI, a small proportion, $4.35 \%$ of the babies, who consumed more than the WHO PTDI for lead will need to be followed up and provided with the necessary health intervention to reduce the risk of $\mathrm{Pb}$ poising.

In respect of the amount of $\mathrm{Cd}$ detected in the breast milk studied, the geometric mean concentration of $1.23 \mathrm{ng} / \mathrm{g}$ of milk $(1.27 \mu \mathrm{g} / \mathrm{L})$ within a range of $0.60-$ $6.30 \mathrm{ng} / \mathrm{g}$ of milk, was lower than that reported by a study in a non-mining area in Ghana, which reported $1.34 \mu \mathrm{g} / \mathrm{L}$ within a range of $0.0-12.30 \mu \mathrm{g} / \mathrm{L}(1.30 \mu \mathrm{g} / \mathrm{g}$ of milk; range of $0.0-11.93 \mu \mathrm{g} / \mathrm{g}$ milk) [28]. This geometric mean was less than those reported $(1.92 \pm 1.04 \mu \mathrm{g} / \mathrm{L}$ (range $0.45-5.87 \mu \mathrm{g} / \mathrm{L}$ )) for an industrial city with an iron foundry, a steel plant, an ordnance plant and a cement plant, [30] and for a city in Poland, which was $2.114 \mu \mathrm{g} / \mathrm{L}$ (range $0.215-7.355 \mu \mathrm{g} / \mathrm{L}$ ) [32]. The However, this was similar to the mean amount of $1.31 \mu \mathrm{g} / \mathrm{L}$ within a range of 0.25 to $2.80 \mu \mathrm{g} / \mathrm{L}$ reported by a study of breast milk obtained from an industrialised city, Madrid in Spain [8]. Furthermore, compared to the mean amount reported for a coastal community of Taiwan, $0.34 \pm 0.19 \mu \mathrm{g} / \mathrm{L}$, the amount of $\mathrm{Cd}$ for our study was much higher [31]. More importantly, this mean Cd amount was slightly higher than the WHO set "normal condition level" in human breast milk, which was $1.0 \mathrm{ng} / \mathrm{mL}$ [0.970 ng/g of milk] [25].

Despite this slightly higher amount, the geometric mean amounts of $\mathrm{Cd}$ the babies consumed through breast milk (Table 4; $0.129 \mu \mathrm{g} / \mathrm{Kg}$ bw/day), was less than the WHO provisional tolerable daily intake (PTDI) for $\mathrm{Cd}$, which of between 0.8 and $1.0 \mu \mathrm{g} / \mathrm{Kg}$ bw/day. Actually, the intake of each of the infants was less than the WHO PTDI (Table 4 shows that the minimum was lower than the WHO PTDI). Therefore, the babies' daily intake of $\mathrm{Cd}$ through breast milk may not pose significant acute risk of $\mathrm{Cd}$ poising, if this is the major source of $\mathrm{Cd}$ among the infants, but may contribute to the accumulation of $\mathrm{Cd}$ in the babies.

In respect of As, although the WHO "normal condition levels" for it in human breast milk are not available, the WHO limits of As in drinking water was used as a standard for comparison. It was determined that the geometric mean of As obtained in this study, which is 26.70 (95\% CI: $22.02-31.39) \mathrm{ng} / \mathrm{g}$ of milk $(27.5 \mu \mathrm{g} / \mathrm{L})$, was about two and half times more than the WHO limits in drinking water (Table 3) and much higher than was reported in a study conducted in a non-mining community in Ghana, which reported a mean of $1.54 \mu \mathrm{g} / \mathrm{L}$ within a range of $0.00-6.22 \mu \mathrm{g} / \mathrm{L}$. This was also much higher than the mean level reported by studies in non-mining and mining communities of other Indonesia, Bangladesh, Tanzania and Zimbabwe, which range between 0.1 and $0.8 \mu \mathrm{g} / \mathrm{L}[28,31,33]$. The resultant geometric mean amounts of As intake by the babies in our study (Table 4), which was $2.90 \mu \mathrm{g} / \mathrm{Kg}$ bw/day, was slightly higher than the WHO PTDI value of $2.1 \mu \mathrm{g} / \mathrm{Kg}$ bw/day and this imply that the potential risk of As poising was higher among the babies in these communities. The finding at the individual level, which showed that $46.36 \%$ of the babies had higher intakes of As then was allowable by WHO PTDI, further shows that almost half of the babies were already at high risk of As accumulation or poising. In respect of As in urine of infants (Table 5), the median concentration reported in this study was much smaller than the median arsenic 
concentration $(14.0 \mu \mathrm{g} / \mathrm{L}$ with an interquartile range (IQR) of 4.5-41.0 $\mu \mathrm{g} / \mathrm{L}$ ) among the population control group in a case control study in a community in Bangladesh known to have high arsenic concentration in their well water, [34].

As indicated by Table 3, the geometric mean amount of $\mathrm{Hg}$ in the breast milk studied, which was 7.61 (95\% CI: 5.14-10.09) ng/g of milk, was about five times higher than the WHO's "normal condition levels" in human breast milk, which is $1.4-1.7 \mathrm{ng} / \mathrm{mL}(1.45-1.77 \mathrm{ng} / \mathrm{g}$ of milk). This geometric mean was also 14 times higher than the mean amount reported by a study in an industrialised city (the BioMadrid study), which reported 0.53 (95\% CI: $0.45-0.62), \mu \mathrm{g} / \mathrm{L}$ of $\mathrm{Hg}$ in breast milk [8]. Also, the mean amount of $\mathrm{Hg}$ reported for a combined sample of breast milk from gold mining communities in Indonesia, Tanzania and Zimbabwe, which was $2.0 \mu \mathrm{g} / \mathrm{L}$, was much lower [35]. These suggest an extreme exposure to $\mathrm{Hg}$ in these mining communities in Ghana and as such they may need urgent intervention.

Also, the resultant geometric mean intake of $\mathrm{Hg}$ through breast milk (Table 4), which was estimated to be 0.940 (95\% CI $0.682-1.197) \mu \mathrm{g} / \mathrm{Kg}$ bw/day was also higher than the WHO PT|DI of $0.57-0.80 \mu \mathrm{g} / \mathrm{Kg}$ bw/day. At the individual level, $33.3 \%$ of the babies had intakes of more the WHO PTDI, while the $66.7 \%$ who had intakes of less than WHO PTDI recorded values just slightly less than the WHO PTDI. Therefore, the risk of $\mathrm{Hg}$ accumulation or poising is high among the babies of these communities and efforts are needed to follow-up and provide intervention as may be necessary to avert the negative influence of $\mathrm{Hg}$ on the development of the babies [36]. The concurrent intake of these toxic metals through breast milk as shown by this study, strongly suggest a significantly high risk of potential effects since there is a multiple exposure to toxic metal at levels that are most likely above the WHO limits for each of the metals.

In assessing whether breast milk, as compared to in utero exposure, was a greater contributor to the exposure of the 3 months old babies to toxic metals, the analysis of $\mathrm{Hg}$ in hair of both mother and baby as well as in breast milk were conducted. It must be noted that toxic metals are mainly eliminated from the mother's body through hair, breast milk and urine, and $\mathrm{Hg}$ serves a good surrogate for mining related toxic metals burden in these biological specimen $[37,38]$. Although the babies consumed breast milk contaminated with $\mathrm{Hg}$, the data presented in Fig. 3 indicates that the babies were exposed to higher levels of $\mathrm{Hg}$ in utero. That is, Since babies are born with hair and these are kept uncut until they are more than 3 months old, the $\mathrm{Hg}$ in the babies' hair could be from both during pregnancy and breast feeding [7, 8, 39-41], however, the median and range of $\mathrm{Hg}$ in the hair of the babies at 3 month old were higher and wider, respectively, than those for the mothers indicating accumulation in utero. Additionally, the median and range of the amount of $\mathrm{Hg}$ in the babies' hair at 9 month (data not shown) was far less than those at 3 months and less than those of the mothers at 3 months, indicating that breast milk, complementary foods and water (not exclusively breastfed beyond 6 months) contributed relatively lesser amounts of $\mathrm{Hg}$ in the babies' hair at 3 months and beyond. In other words, exposure of babies to toxic metals in these mining communities in Ghana is much more during pregnancy (in utero) than through breast feeding (post-partum). This was contrary to the findings of a study of mother-baby pairs in a high fish consuming tin mining community in Brazil [37].

The study did not assess the mothers' other sources of $\mathrm{Hg}$ contamination, primarily their consumption of fish, and the babies consumption of fish as part of their complementary food beyond 3 months old, since the babies were predominately (but without food) breast fed until after 3 months post-partum. Additionally, this study did not speciate the detected toxic metals, particularly for mercury. Furthermore, the mothers and/or their husbands in both areas were not asked to provide information indicating they were actually working in mining and for how long, due to ethical implications, which is, because most of the artisanal mining are not registered, not regularized, mostly take place mostly within allocations of regular mining company and current negative press, therefore participants were not willing to provide such information because they fear arrest, victimisation or/and loss of livelihood.

\section{Conclusions}

An appreciable proportion of babies living within the communities served by the Mangoasi Community Hospital in the Obuasi Municipality of the Ashanti Region and the Dompime Health Centre in the Tarkwa Municipality of the Western Region are exposed to $\mathrm{Hg}$, $\mathrm{As}$ and $\mathrm{Pb}$ through breast milk in excess of what they should. In addition, although the exposure of these babies to $\mathrm{Cd}$ was not in excess of WHO standards, there is the urgent need to monitor and provide intervention to avert the detrimental developmental effects of these toxic metals on the growth of the babies and therefore, the future effect on the economy of the Municipalities and Ghana as a whole.

\section{Abbreviations}

PTDI: Provisional Tolerable Daily Intake; DEM: Deuterium Enrichment Method; FTIR: Fourier Transformed Spectrometry; PTWI: Provisional Tolerable Weekly Intake; DPI: Daily Permissible Intake

\section{Acknowledgements}

The authors are grateful to the following The Ghana Ministry of Health, the District Directors of Health Services and the Staff of the Dompime Health Centre in the Tarkwa Municipality of the Western Region as well as the staff of the Mangoasi Community Hospital in the Obuasi Municipality of the Ashanti Region for hosting and supporting this study in various ways during the field work. Dr. Emmanuel Nii 
Boye Hammond and Professor IJ.K Aboh, both of the Ghana Atomic Energy Commission, for their immense support and contributions during the seeking for funding. The will like to thank Dr. Christine Slater of the IAEA for her technical and logistical support on this project.

\section{Availability of data and materials}

The datasets generated and analysed during this study are not publicly available due to the fact that the application for ethical approval and the informed consent did not include making the datasets publicly available. However, these, as well as the questionnaire designed by the International Atomic Energy Agency for this study, may be available from the corresponding author on reasonable request.

\section{Funding}

International Atomic Energy Agency (IAEA) funding under the Africa Regional Project Number RAF6039. The IAEA were involved in the design of a generic study and related questionnaire, for a multi-country study. The investigators in each country modified the design of the study and questionnaire to suit the context of their country. Although the funding organisation provided the deuterium water, they did not participate in the collection of data. Furthermore, although the Funding Organisation provided training for data management and analysis, they did not participant in any way in the analysis, interpretation of data and in writing the manuscript of the country-specific data, which for Ghana is the data analysed, interpreted and presented in this report.

\section{Authors' contributions}

$\mathrm{DB}, \mathrm{RB}, \mathrm{TA}$, and WO made substantial contributions to conception and design of the study. DB, ECB-A, KA, DD, AD, RB, and TA were involved in the acquisition of data. AKA, DB, ECB-A, KA, DD, and AD were involved in the management, analysis and interpretation of data. AKA and ECB were involved in drafting the manuscript: All authors were involved in revising manuscript critically for important intellectual content. All authors given final approval of the version to be published. All authors agreed to be accountable for all aspects of the work in ensuring that questions related to the accuracy or integrity of any part of the work are appropriately investigated and resolved.

\section{Competing interests}

The authors of this paper declare they have no competing interest in this study.

\section{Consent for publication}

Not applicable.

\section{Ethics approval and consent to participate}

The study was approved by the Ethics Review Committee of the Ghana Health Service. Additionally approvals for the study were obtained from the Ghana Health Service and the individual Hospital Administrations. Written informed consent was obtained from each participating mother. Further description of the ethical considerations are provided in the method section.

\section{Publisher's Note}

Springer Nature remains neutral with regard to jurisdictional claims in published maps and institutional affiliations.

\section{Author details \\ 'Nutrition Research Centre, Radiological and Medical Sciences Research Institute, Ghana Atomic Energy Commission, Accra, Ghana. ${ }^{2}$ Cellular and Clinical Research Centre, Radiological and Medical Sciences Research Institute, Ghana Atomic Energy Commission, Accra, Ghana. ${ }^{3}$ Nutrition Department, Ghana Health Service, Accra, Ghana.}

Received: 18 January 2017 Accepted: 9 May 2017

Published online: 25 May 2017

\section{References}

1. Fanali G, di Masi A, Trezza V, Marino M, Fasano M, Ascenzi P. Human serum albumin: From bench to bedside. Mol Asp Med. 2012:33:209-90.

2. Pozzi CMC, Braga CP, Vieira JCS, Cavecci B, Vitor de Queiroz J, de Souza Barbosa $\mathrm{H}$, et al. Metal ions bound to the human milk immunoglobulin A: Metalloproteomic approach. Food Chem. 2015;166:492-7.
3. Odintsova ES, Zaksas NP, Buneva VN, Nevinsky GA. Metal dependent hydrolysis of $\beta$-casein by slgA antibodies from human milk. J Mol Recognit. 2011;24:45-59

4. Örün E, Yalçın SS, Aykut O, Orhan G, Morgil GK, Yurdakök K, et al. Breast milk lead and cadmium levels from suburban areas of Ankara. Sci Total Environ. 2011:409:2467-72

5. Dórea JG, Marques RC, Isejima C. Neurodevelopment of Amazonian Infants: Antenatal and Postnatal Exposure to Methyl- and Ethylmercury. J Biomed Biotechnol. 2012;2012:1-9.

6. Llop S, Guxens M, Murcia M, Lertxundi A, Ramon R, Riano I, et al. Prenatal Exposure to Mercury and Infant Neurodevelopment in a Multicenter Cohort in Spain: Study of Potential Modifiers. Am J Epidemiol. 2012;175:451-65.

7. Dórea JG, Bezerra VLVA, Fajon V, Horvat M. Speciation of methyl- and ethylmercury in hair of breastfed infants acutely exposed to thimerosalcontaining vaccines. Clin Chim Acta. 2011:412:1563-6.

8. García-Esquinas E, Pérez-Gómez B, Fernández MA, Pérez-Meixeira AM, Gil E, de Paz $C$, et al. Mercury, lead and cadmium in human milk in relation to diet, lifestyle habits and sociodemographic variables in Madrid (Spain). Chemosphere. 2011;85:268-76.

9. Donkor A, Nartey V, Bonzongo J, Adotey D. Artisanal mining of gold with mercury in Ghana. West Afr J Appl Ecol. 2009;9. doi:10.4314/wajae.v9i1.45666.

10. Rajaee M, Sánchez B, Renne E, Basu N. An Investigation of Organic and Inorganic Mercury Exposure and Blood Pressure in a Small-Scale Gold Mining Community in Ghana. Int J Environ Res Public Health. 2015;12:10020-38.

11. Bannerman W, Potin-Gautier M, Amoureux D, Tellier S, Rambaud A, Babut $M$, et al. Mercury and arsenic in the gold mining regions of the Ankobra River basin in Ghana. J Phys IV Proc. 2003;107:107-10.

12. Bonzongo J-CJ, Donkor AK, Nartey VK, Lacerda LD. Mercury Pollution in Ghana: A Case Study of Environmental Impacts of Artisanal Gold Mining in Sub-Saharan Africa. In: Drude de Lacerda L, Santelli RE, Duursma EK, Abrão JJ, editors. Environmental Geochemistry in Tropical and Subtropical Environments. Berlin: Springer Berlin Heidelberg; 2004. p. 135-56. http://link.springer.com/10.1007/978-3-662-07060-4_12. Accessed 15 Jan 2016.

13. Golow AA, Mingle LC. Mercury in River Water and Sediments in Some Rivers near Dunkwa-On-Offin, an Alluvial Goldmine, Ghana. Bull Environ Contam Toxicol. 2003:70:379-84

14. Adimado AA, Baah DA. Mercury in human blood, urine, hair, nail, and fish from the Ankobra and Tano River Basins in southwestern Ghana. Bull Environ Contam Toxicol. 2002:68:339-46.

15. Golow AA, Adzei EA. Mercury in surface soil and cassava crop near an alluvial goldmine at Dunkwa-on-Offin, Ghana. Bull Environ Contam Toxicol. 2002;69:228-35

16. Amonoo-Neizer EH, Nyamah D, Bakiamoh SB. Mercury and arsenic pollution in soil and biological samples around the mining town of Obuasi, Ghana. Water Air Soil Pollut 1996:91:363-73.

17. Chang J, Park J, Shin S, Yang H, Moon J, Ko J. Mercury Exposure in Healthy Korean Weaning-Age Infants: Association with Growth, Feeding and Fish Intake. Int J Environ Res Public Health. 2015;12:14669-89.

18. Moore SE, Prentice AM, Coward WA, Wright A, Frongillo EA, Fulford AJ, et al. Use of stable-isotope techniques to validate infant feeding practices reported by Bangladeshi women receiving breastfeeding counseling. Am J Clin Nutr. 2007;85:1075-82.

19. Ettyang GA, Lichtebelt van M, Esamai F, Saris WH, Westerterp K. Assessment of body composistion and breast milk volume in lactating mothers in Pastoral communities in Pokot, Kenya, using deterium Oxide. Ann Nutr Metab. 2005:49:110-7.

20. Galpin L, Thakwalakwa C, Phuka J, Ashorn P, Maleta K, Wong WW, et al. Breast Milk Intake is not reduced more by the introduction of energy dense complementary food than typical infant porridge. J Nutr. 2007;137:1828.

21. Infante C, Hurtado J, Salazar G, Pollastri A, Aguirre E, Vio F. The dose-tomother method to measure milk intake in infants by deuterium dilution: A validation study. Eur J Clin Nutr. 1991:45:121-9.

22. da Costa THM, Haisma H, Wells JCK, Mander AP, Whitehead RG, Bluck LJC. How much human milk do infants consume? Data from 12 countries using a standarized stable isotope methodology. J Nutr. 2010;140:2227-32.

23. Rosetta L, Kurpad A, Mascie-Taylor CGN, Shetty PS. Total energy expenditure $(18 \mathrm{H} 2 \mathrm{O})$, physical activity level and milk output of lactating rural Bangladeshi tea workers and nontea workers. Eur J Clin Nutr. 2005;59:632-8. 
24. Haisma H, Coward WA, Albernaz E, Visser GH, Wells JCK, Wright A, et al. Breast milk and energy intake in exclusively, predominantly, and partially breast-fed infants. Eur J Clin Nutr. 2003;57:1633-42.

25. Parr RM, DeMaeyer EM, lyengar VG, Byrne AR, Kirkbright GF, Schöch G, et al. Minor and trace elements in human milk from Guatemala, Hungary, Nigeria, Philippines, Sweden, and Zaire: Results from a WHO/IAEA joint project. Biol Trace Elem Res. 1991;29:51-75.

26. Vahter M, Berglund M, Åkesson A, Lidén C. Metals and Women's Health. Environ Res. 2002;88:145-55.

27. Ettinger AS, Téllez-Rojo MM, Amarasiriwardena C, Peterson KE, Schwartz J, Aro $\mathrm{A}$, et al. Influence of maternal bone lead burden and calcium intake on levels of lead in breast milk over the course of lactation. Am J Epidemiol. 2006;163:48-56.

28. Bentum JK, Sackitey OJ, Tuffuor JK, Essumang DK, Koranteng-Addo EJ, Owusu-Ansah E. Lead, Cadmium and Arsenic in breast milk of lactating mothers in Odumanse-Atua community in Manya Krobo district of eastern region of Ghana. J Chem Pharm Res. 2010;2:16-20.

29. Vanderlagt DJ, Okolo SN, Romero L, Millson M, Glew RH. Lead levels in the milk of Fulani women in Nigeria. J Natl Med Assoc. 2001;93:104-8.

30. Goudarzi M, Parsaei P, Nayebpour F, Rahimi E. Determination of mercury, cadmium and lead in human milk in Iran. Toxicol Ind Health. 2013;29:820-3.

31. Chao H-H, Guo C-H, Huang C-B, Chen P-C, Li H-C, Hsiung D-Y, et al. Arsenic, cadmium, lead, and aluminium concentrations in human milk at early stages of lactation. Pediatr Neonatol. 2014;55:127-34.

32. Winiarska-Mieczan A. Cadmium, Lead, Copper and Zinc in Breast Milk in Poland. Biol Trace Elem Res. 2014;157:36-44.

33. Islam MR, Attia J, Alauddin M, McEvoy M, McElduff P, Slater C, et al. Availability of arsenic in human milk in women and its correlation with arsenic in urine of breastfed children living in arsenic contaminated areas in Bangladesh. Environ Health. 2014;13 doi:10.1186/1476-069X-13-101.

34. George CM, Brooks WA, Graziano JH, Nonyane BAS, Hossain L, Goswami D, et al. Arsenic exposure is associated with pediatric pneumonia in rural Bangladesh: a case control study. Environ Health. 2015;14 doi:10.1186/ s12940-015-0069-9.

35. Bose-O'Reilly S, Lettmeier B, Roider G, Siebert U, Drasch G. Mercury in breast milk - A health hazard for infants in gold mining areas? Int J Hyg Environ Health. 2008;211:615-23.

36. Rajaee M, Long R, Renne E, Basu N. Mercury Exposure Assessment and Spatial Distribution in A Ghanaian Small-Scale Gold Mining Community. Int J Environ Res Public Health. 2015;12:10755-82.

37. Marques RC, Bernardi JVE, Dórea JG, Leão RS, Malm O. Mercury Transfer During Pregnancy and Breastfeeding: Hair Mercury Concentrations as Biomarker. Biol Trace Elem Res. 2013;154:326-32.

38. Chen G, Chen X, Yan C, Wu X, Zeng G. Surveying Mercury Levels in Hair, Blood and Urine of under 7-Year Old Children from a Coastal City in China. Int J Environ Res Public Health. 2014;11:12029-41.

39. Gareri J, Koren G. Prenatal hair development: Implications for drug exposure determination. Forensic Sci Int. 2010;196:27-31.

40. Mohan S, Tiller M, van der Voet G, Kanhai H. Mercury Exposure of Mothers and Newborns in Surinam: A Pilot Study. Clin Toxicol. 2005:43:101-4

41. Dorea JG. Mercury and lead during breast-feeding. Br J Nutr. 2004;92:21.

\section{Submit your next manuscript to BioMed Central and we will help you at every step:}

- We accept pre-submission inquiries

- Our selector tool helps you to find the most relevant journal

- We provide round the clock customer support

- Convenient online submission

- Thorough peer review

- Inclusion in PubMed and all major indexing services

- Maximum visibility for your research

Submit your manuscript at www.biomedcentral.com/submit

\section{O) Biomed Central}

